\section{考案}

症例 1 は大動脈炎症候群に動脈瘤発生傾向が強い1) の実感がなかった 10 余年前の経験である.9 年前に移 植した graft は著しく短縮し, 吻合部は腎動脈分岐部の 高さまで挙上し，周囲との癒着が強く wrapping 不可 能であった．本例で頻回の吐・下血にかかわらず穿孔所 見が軽かったことより, 症例 2 においても類似所見を想 定し, かつ人工血管置換施行の関係上, 感染誘発の危惧 のある瘤壁の積極的検索, 腸管切除や腸㾞造設などは敢 えて回避した．遺残大動脈瘤内腔への大網膜挿入固定も 考慮はしたが，実施しなかった，症例 2 において血清ビ リルビン值が高值を示し肝不全状態をさたしたのは, 低
酸素状態执よび大量の保存血輸血によるものも一因であ $\eta^{2)}$ ，腹腔内に漏出した胆汁の再吸収も一因であろうと 思われる。

\section{結 語}

腹部大動脈瘤の上部腸管への破裂穿孔は代用血管での 修復を要し，必ず感染を伴い，上部腸管の適正な処置を 講ずることが困難であることから一般に，予後は不良で ある。

文 献 1) 勝村達喜注か:脈管学 $21: 319: 1981$ 2) 岡本 好史注か: 手術 $38: 1327,1984$

\title{
37 胸腹部大動脈瘤の手術経験
}

岩手県立中央病院 心臓血管外科
小山田 恵 石 川 茂 弘 佐 藤 尚 長 嶺 進
垣 畑 秀 光

これまでわれわれの施設において行った胸腹部大動脈 瘤 3 例について報告する。

3 例すべて大動脈の退行性変性に由来する真性動脈瘤 で部位的には胸部下行大動脈から腹腔動脈分岐部までの もので Crawford らの分類 I Aタイプに属するものであ る.

\section{症例}

症例 162 歳女.

数年来高血圧の治療をらけていたが最近胸部痛と動悸 を訴えて来院, 胸部 $\mathrm{X}$ 線写真から大動脈瘤との診断で入 院した．動脈造影では第 4 胸椎の高さの下行大動脈から 横隔膜を越え腹腔動脈分岐部までの動脈瘤が認められ， この区間の肋間動脈もすべて造影された。 昭和 52 年 10 月 5 日手術施行. 左第 5 肋間開胸胁骨弓, 横隔膜を切開こ れを腹部まで延長して大動脈瘤を露出した。大動脈瘤は 左鎖骨下動脈分岐部より $5 \mathrm{~cm}$ 下から下方は腹腔動脈分 岐部まで, 動脈瘤長さ $215 \mathrm{~mm}$ 最も太い個所での横径 88 $\mathrm{mm}$ であった．左鎖骨下動脈直下と股動脈間に external long bypass を施行後大動脈を遮断，動脈瘤を切開，瘤 内血栓を除去し，3 対の肋間動脈を瘤内から縫合を行い
次いで径 $20 \mathrm{~mm}$ のダクロングラフトを intraluminal に吻合した．吻合終了後瘤壁を縫合しグラフトを内没さ せた，対麻痺に対する予防としては術中の脊䯣液持続吸 引，術中，術後のマンニットール副腎皮質ステロイド投 与を行った，術後なんら合併症なく 8 年経過している. 症例 266 歳女.

5 年前から高血生の治療をらけていたが昭 和 51 年 10 月 3 日, 突然背部痛あり救急車で入院解離性大動脈瘤の 疑いで検查をうけた．動脈造影所見は症例 1 と同様胸部 下行大動脈から腹腔動脈分岐部までの胸腹部大動脈瘤 で，この区間の肋間動脈注開存していた．昭和 53 年 4 月 13 日手術施行, 胸腹部にわたる全長 $120 \mathrm{~mm}$, 最大径 $56 \mathrm{~mm}$ の動脈瘤に対し症例 1 とまったく同様の手術 法 によって径 $20 \mathrm{~mm}$ のダクロングラフト吻合術を行っ た. 術後合併症なく 7 年経過した.

症例 3 (表 1 ) 55 歳男。

昭和 59 年 10 月からせきが止まらず治療をらけていた がしだいに気道圧迫呼吸困難が増強して某病院に入院. 胸部レ線写真，扣よび CT で多発性動脈瘤と診断され 当科に転科した，動脈造影では，左腕頭動脈の鑜骨下動 脈分岐部，胸部下行大動脈から腹腔動脈分岐部までの胸 
腹部大動脈，それに胃動脈以下両側総腸骨動脈にとれぞ れ巨大な動脈瘤の存在が確認された。手術は 2 回に分 け, 第 1 回目の手術は昭和 59 年 11 月 26 日頸部ならび に胸骨正中切開にて上行大動脈から右総頸動脈および右 鎖骨下動脈にそれぞれ別個に径 $8 \mathrm{~mm}$ のゴアテックス 人工血管によるバイパス手術を施行した後腕頭動脈瘤へ の出入部でこれらの血管を結禁した.

第 2 回目は昭和 59 年 12 月 17 日, まず腹部正中切開 にて腎動脈分岐部以下の腹大動脈, 総腸骨動脈に $\mathrm{Y}$ 字型 グラフト（径 $22 \mathrm{~mm}$ 㧊よび $10 \mathrm{~mm}$ ） による人工血管移 植術を行いらいでこの人工血管の側壁に別の長いグラフ 卜（径 $22 \mathrm{~mm}$ ) を吻合し，これを後腹膜腔から横隔膜 を貫いて左胸腔に導き，胸腹部大動脈瘤の中枢側で胸部 大動脈と端側吻合した。吻合終了後この吻合部のすぐ末 梢部で下行大動脈を遮断. この際, 橋本式パーマネント， アオルチッククランプ（長さ $70 \mathrm{~mm}$ ) を使用した。 た腹腔動脈分岐部直前の腹大動脈に対してはテープによ り部分遮断を行い瘤の破裂防止之肋間動脈の温存をはか った．術終了時上肢血圧は収縮期圧 $120 \mathrm{mmHg}$ でこれ に対し瘤内压は $80 \mathrm{mmHg}$ を示したが圧波型は平坦であ った．この例では一時的バイパスを含め，体外循環はい
表 1 多発性大動脈瘤 (55歲 男)

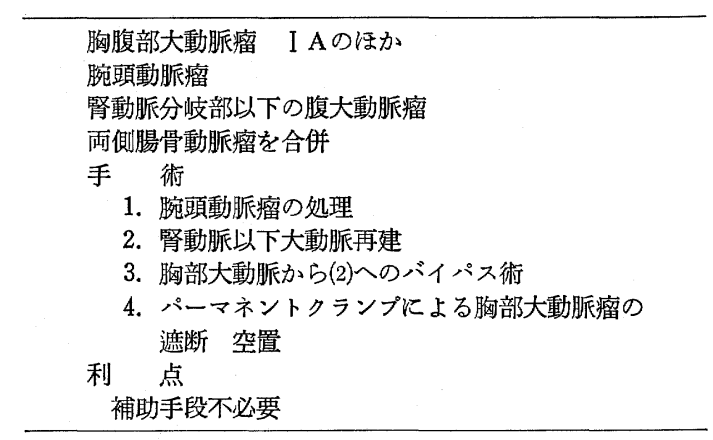

っさい使用せずしたがってヘパリンの全身投与も行わ ず, 術中術後すべて順調に経過し, 症状は緩快して元気 に退院した.

\section{結語}

胸腹部大動脈瘤の手術に際し最も問題となるのは術後 の対麻痺をいかにして予防するかである．理想的には肋 間動脈を温存する方法であるが実際の臨床上それが行い にくい場合にはわれわれの行った方法も次善の方策とし て評価されるものと考兄る。 